International Journal of Child, Youth and Family Studies (2012) 2 \& 3: 331-348

\title{
MORE EQUAL THAN OTHERS: THE DISCURSIVE CONSTRUCTION OF MIGRANT CHILDREN AND FAMILIES IN CANADA
}

\section{Lara di Tomasso}

\begin{abstract}
As borders become increasingly porous to the flow of global capital, human beings entering countries like Canada are routinely criminalized. On August 13, 2010, the Canadian Navy escorted the MV Sun Sea, a ship carrying 492 men, women, and children from Sri Lanka, to a Canadian Forces Base on Vancouver Island. Many months later, people remained imprisoned. The racialization, criminalization, and detention of migrant children and families in Canada poses a direct challenge to the notion of Canadian multiculturalism, as well as purported commitments to the rights of children. This paper seeks to critically engage with dominant narratives surrounding the arrival and treatment of the 492 men, women, and children aboard the MV Sun Sea in order to unmask and explore the multitude of discourses required to normalize the criminalization of people's bodies.
\end{abstract}

Keywords: Canada, migrants, racialization, critical multiculturalism, discourse analysis

Lara di Tomasso received a BA in Political Science from McGill University in 2003, and is currently completing her Master's in Child and Youth Care at the University of Victoria, P.O. Box 1700, STN CSC, Victoria B.C., Canada, V8W 2 Y2. Email: Lara.dito@gmail.com 
International Journal of Child, Youth and Family Studies (2012) 2 \& 3: 331-348

On August 13, 2010, the Canadian navy escorted the MV Sun Sea, a ship carrying 492 men, women, and children from Sri Lanka, to a Canadian Forces Base on Vancouver Island. Months later, people remained imprisoned in British Columbia, including women and children. This paper seeks to critically engage with selected texts that illuminate some of the dominant narratives surrounding the arrival and treatment of the 492 men, women, and children aboard the MV Sun Sea. The public comments sections of two online articles from the Canadian Broadcasting Corporation (CBC) website will be used as sources for discourse analysis. The intention is to use this paper as an opportunity to unmask and explore the multitude of discourses required to normalize the construction of migrants' bodies as illegal and justify the detention of (certain) children and families. What might this exploration reveal about Other(ed) childhoods and families in Canada? As child and youth care professionals, how might we position ourselves in order to better support children and families in this rapidly changing and contradictory context?

\section{The Canadian Context}

Before embarking on an examination of the Canadian public's reaction to the arrival of Tamil migrants in July 2010, it is imperative to consider the context into which the migrants arrived. The following sections will address how discourses of national security, multiculturalism, and neo-liberalism intersect with processes of racialization. This will be undertaken with the recognition that all of these elements are inextricably bound together in complex relationships and cannot be separated out from one another.

\section{Racialization}

Racialization describes a dynamic process whereby race is constructed and negotiated according to systems of power in specific temporal contexts and places. I use this term as an intentional alternative to conceptualizing race as static, and based primarily on phenotype. Notions of whiteness and discourses of racialization are fluid, and always changing over time and in relation to others. Once we become aware of this process, race is no longer knowable simply through phenotype or country of origin, but rather through a complex process involving power and collective meaning making. In white settler societies such as Canada, whiteness is not racialized but normalized and thus rendered invisible. Citing the work of John Gabriel, Jiwani (2006) refers to this as the power of exnomination, or the power not to be named. This creates the backdrop against which the "Other" is created by dominant society (Jiwani, 2006). Therefore, racialization is a process of constructing a hierarchy of identities through distinctions between "Us" and "Them".

\section{Racialization and Canadian Multiculturalism}

Multiculturalism serves to both shore up and mask processes of racialization in several important ways. Multiculturalism is official policy in Canada, and constitutes an important part of the nation's collective imaginary. Drawing from the work of Eva Mackey (1999), collective or national imaginary refers to how national identity is 
International Journal of Child, Youth and Family Studies (2012) 2 \& 3: 331-348

imagined, or conjured, through the stories that the nation and its citizens tell themselves. The Canadian government frequently reiterates that Canada is defined through the way in which it welcomes, tolerates, and accommodates people from all over the world.

Canada's Citizenship and Immigration Minister, Jason Kenney, stated in a speech at the University of Western Ontario, "One of the unique things about Canada ....is that we probably have the strongest pro-immigration consensus in our political system of any comparable country. ... At the same time we have this tradition, as I mentioned, of embracing diversity, grounded in our historic, I would say British liberal imperial, tradition of pluralism...” (Kenney, 2009). It is worth noting that in this speech, and in other government proclamations regarding Canada's unmatched hospitality and benevolence, statistics reflecting how many migrants reside in Canada are listed off, as though the sheer presence of migrants in large numbers is evidence enough of colourblind Canadian hospitality. Very seldom, if ever, do narratives of multiculturalism address the racialized nature of poverty, prison populations, and children in government care. These realities are in fact antithetical to multiculturalism discourse.

Multiculturalism is envisioned as, "an ongoing process that includes comfort with, and support and nurturance of people from various cultures ...” (Hoopes, 1979, as cited in Robinson, 2000, p. 3). However, Pacini-Ketchabaw, White, and Armstrong de Almeida (2006) argue that the intention behind multicultural policy is to facilitate more thorough assimilation into the dominant culture by inviting people to feel secure in their ethnic origins (p. 104). Multiculturalism has become the primary lens through which Canadians understand issues of diversity. It has influenced the design of "culturally sensitive” curriculum from preschool to university and has informed cultural sensitivity training in the workplace.

Multicultural language is itself rooted in ideological constructions of racialized communities, and serves as a vehicle for racializations (Bannerji, 2000). Official multicultural policy relies on the "Us/Them" binary described above as it posits an imagined core Canadian culture against various multicultures (Bannerji, 2000). The underlying concepts of official multiculturalism are not complex enough to permit an understanding of people's nuanced identities. Bannerji (2000) asserts that non-white immigrants are hardened into groups by a system that needs them to be organized as such so that policies can then be designed to target institutionally recognized communities. This leads to race itself becoming culturalized (Razack, 1998, as cited in Jiwani, 2006, p. 14).

Within this paradigm, the culturalized are perceived to be ruled by culture, while whiteness, which is not culturalized, assumes the ability to rule oneself, but enjoy culture (Brown, 2006). Within multicultural discourse, Canadian culture is conceived of as normative, hegemonic whiteness (Pacini-Ketchabaw et al., 2006). The confusion of "Canadianness" with "whiteness" is entrenched in colonial mythologies about the presumed white, European origins of "real Canadians". The conflation of race and culture reinforces hegemonic whiteness by perpetually relegating racialized people, including Aboriginals and Canadian-born citizens, to subjectivities ulterior to "Canadian”. Brown (2006) posits that liberalism is imagined as the bridge between those who rule 
International Journal of Child, Youth and Family Studies (2012) 2 \& 3: 331-348

themselves, and those who are ruled by culture in Western societies, whereby liberalism itself is not recognized as being a cultural production (pp. 20-21). The distinction between those who rule themselves and those who cannot is a dangerous one. It can be mobilized to justify invasive and violent policies that target communities perceived as being confined within culture, and thus deemed in need of such interventions "for their own good”.

Tolerance language is integral to Canadian multiculturalism discourse, which masks systemic inequality and racism in several important ways. First, notions of tolerance and decency are absorbed into the national identity and become understood as distinguishing values of the nation (Anderson \& Taylor, 2005). This necessarily positions "Othered" nations, cultures, and people as lacking these values, and potentially as incapable of possessing them. Secondly, liberal multiculturalism puts forth a discourse of colour-blindness that constructs racism as aberrational or, more precisely, as the symptom of individual pathology (Pacini-Ketchabaw et al., 2006). Lastly, multiculturalism contributes to the authorship of powerful cultural mythologies about equality of opportunity and access to power. As a consequence, systemic barriers to substantive equality are ignored and socially constructed conditions like poverty become ontologized (Bannerji, 2000).

It is important to consider Kamboureli's (2000) observation that Canadian society is currently experiencing "multicultural fatigue". This fatigue stems from dominant society's assumption that multiculturalism has fulfilled, if not exceeded, its mandate (Kamboureli, 2000). This assumption is rendered visible in the type of brazen impatience and indignation displayed during the reasonable accommodations debates in Québec, Canada in 2007, where one of the common refrains was that Québecers had reached the limits of their tolerance and felt that it was time to put their collective foot down and reassert their own cultural values. This manifested itself in the development of a document, which all new immigrants to the province are obliged to sign, promising to respect Québec’s essential values.

\section{Racialization and Security Discourse}

One of the key features of the present Canadian socio-political landscape, which serves to delineate the ways in which dominant culture constructs race and conceptualizes issues of migration, is a preoccupation with national security. What and who Canada believes itself to be, who Canada believes itself to be threatened by, why, and measures undertaken in the name of protection, all shape a security discourse that has far-reaching implications for how race, diversity, and migration are widely understood. Since September 11, 2001, racialized stereotypes have been mobilized to construct Muslims, Arabs, and South Asians (and all those who fit these stereotypes) as suspects through a security discourse that serves to criminalize their communities (Smolash, 2009, p. 746). “This 'enemy' position within security discourse is understood in the national imaginary as essentially outside the 'Us' of Canadian identity”' (Smolash, 2009, p. 754). 
International Journal of Child, Youth and Family Studies (2012) 2 \& 3: 331-348

Since 2001, we have seen individual rights trampled, and the intensification of violent state interventions directed at specific communities, such as increased detentions and deportations. These forms of sanctioned state violence are racialized in that those targeted are predominantly the "Them” constructed through mainstream discourse.

\section{Racialization and Neo-liberalism}

Neo-liberalism is both constituted by and constitutive of dominant North American cultural values and perceptions. In contemporary Canadian society, it seems as though it is possible to assign everything - and everyone - a quantitative value. It has become increasingly difficult to make the case for afore-considered basic social services without including a quantitative assessment of anticipated economic outcomes. AbuLaban and Gabriel (2008) succinctly state, “...there is increasing emphasis on the economic or potential economic contributions of individuals as the sum worth of a person” (p. 52).

Neo-liberalism ties into processes of racialization in several important ways. First, as with other culturally entrenched Western discourses, neo-liberalism focuses on the individual as a separate, agentic unit. Success (wealth) is the product of hard work, and failure (poverty) is attributable to personal shortcomings. Second, as Roberts and Mahtani (2010) assert, neo-liberalism both contributes to the production of racialized bodies and modifies the ways in which race functions (p. 248). They point out that neoliberal policies disproportionately impact racialized populations, and then work to ensure that, "racial identity and racism is subsumed under the auspices of meritocracy" (p. 253). In other words, neo-liberal discourse perpetuates the falsehood that wealth and power deservingly go to those who merit them through hard work. Therefore, the myth of meritocracy, another of the powerful stories that constitutes the Canadian national imaginary, works to render invisible issues of power, privilege, oppression, and processes of racialization.

The rise of neo-liberalism has had a direct impact on Canadian immigration policy. While the purpose of immigration policy has always been to exclude people, the neo-liberal emphasis on finding skilled labour emphasizes gender, class, ethnic, and racial biases and hierarchies (Abu-Laban, 1998). There is immense pressure on immigrants to rapidly become "productive" members of society. It is important to note that concurrent with the rise of neo-liberalism, there has been "profound and lasting deterioration" in the kind of economic success experienced by immigrants prior to the 1980s (Picot \& Hou, 2003, Grant \& Sweetman, 2004, both as cited in Biles, Burstein, \& Frideres, 2008, p. 7). Higher than ever percentages of newcomers experience low incomes, and poverty in Canada is increasingly concentrated in racialized migrant communities (Access Alliance, 2007). In a survey conducted on the intersection of poverty, race, and access to health care among racialized children in Toronto, the Access Alliance Multicultural Community Health Centre found that racialized children constituted $75 \%$ of all children in low-income households. Furthermore, the low-income rate was highest for children who had recently arrived in Canada (Access Alliance, 2007). 
International Journal of Child, Youth and Family Studies (2012) 2 \& 3: 331-348

\section{Detention, Deportation, and Nation Building}

The arbitrary lines that we know as borders delineate the spaces within which state sovereignty is performed. Colonial powers drew these lines, and current colonial powers enforce and manipulate them. It is important to understand detention and deportation as both preventive and punitive technologies that play a role in constructing and legitimizing citizens and countries (Pratt, 2005). The state-imposed violence exerted through the detention and deportation of migrants (Jiwani, 2006) is intended to deter would-be migrants as much as it is a mechanism of control over Canada's borders. Pratt (2005) explains that because overly racist and ideological grounds for exclusion have been de-legitimized through the human rights language of past decades, detention and deportation are presently explained through discourses of crime and security.

As discussed above, the post-9/11 mentality of imminent and perpetual threat has given rise to a context wherein preoccupations with crime and security act upon refugee claimants in dangerous ways (Pratt, 2005). Canada's refugee system has shifted its focus from offering safe refuge to asylum seekers, to keeping Canada safe from "deceitful” and "dangerous" refugee claimants. Justified in this way, the technologies of detention and deportation become understood as inevitable and predictable consequences to perceived violations of state sovereignty (De Genova \& Peutz, 2010).

Migration across space challenges the very existence of present-day conceptions of bounded, sovereign nation-states. Skott-Myhre (2008) asserts:

The nation state for example would like to portray itself as a well-contained and bounded space. It wants to suggest that its borders are well established and clear. The immigration services, laws, and regulations imply tight control over the flow of bodies between states, and yet we know that the nation state is in fact porous; that bodies flow across borders in huge waves on immigration and exodus. (p. 82)

The policing of borders then, and the employment of tactics such as detention and deportation, are produced by and through ideas that constitute what "Canada" is. The exclusionary practices of immigration regimes worldwide are a form of legalized discrimination, which through exclusion, justify the continued existence of the anachronistic concept of the nation-state (De Genova \& Peutz, 2010).

Finally, detention and deportation inherently constitute migrants as guilty of having perpetrated some sort of crime. Smolash (2009) suggests that, "the visibility of punishment by state power produces the guilty body, at once creating a particular identity and creating public knowledge of the visible clarity of guilt” (p. 750). The above sections elucidate how public perception of migrants is shaped in part by the punitive acts undertaken by the government against them, as well as through converging discourses of racialization, national security, multiculturalism, and neo-liberalism. 
International Journal of Child, Youth and Family Studies (2012) 2 \& 3: 331-348

\section{Refugee Claims in Canada Contextualized}

Of the estimated 43.3 million displaced people worldwide in 2009 (United Nations High Commission for Refugees, 2010), 33,161 people claimed asylum in Canada that same year (Citizenship and Immigration Canada, 2010). Every day, people arrive at land borders and airports in Canada and claim asylum. There is no queue for refugee claimants, and no orderly bureaucratic process expected to be undertaken in their country of origin. The refugee claims of the 492 Tamil migrants aboard the Sun Sea in July of 2010 represent $2 \%$ of the total number of asylum claims registered in Canada that year (Canadian Council for Refugees, 2011). Most refugee claimants are processed at a land border or airport, and then directed towards a community agency that provides housing and basic services. This is mentioned intentionally in order to emphasize that the wholesale detention of the Tamil passengers of the Sun Sea is an anomaly in the Canadian context that requires deconstruction. Furthermore, the Canadian government insists that it does not officially detain migrant children, it simply allows children to accompany their parents into detention (J. Will [lawyer], personal communication, February 9, 2011). In Section 60 of the Immigrant and Refugee Protection Act (IRPA), "it is affirmed as a principle that a minor child shall be detained only as a measure of last resort, taking into account the other applicable grounds and criteria including the best interests of the child" (Department of Justice Canada, 2001).

Which children then are guaranteed that their best interests will be protected, and their rights upheld? It certainly does not seem that the best interests of the children from the MV Sun Sea were considered when their families were automatically detained upon arrival.

Refugees are considered under international law as having fled persecution, and refugee claimants are thus entitled to a fair evaluation of their claims. Canada is a signatory to the 1951 United Nations Convention Relating to the Status of Refugees, and its 1967 protocol. The Convention defines a refugee as a person who, "owing to a wellfounded fear of being persecuted for reasons of race, religion, nationality, membership in a particular social group, or political opinion, is outside the country of his nationality, and is unable to or, owing to such fear, is unwilling to avail himself of the protection of that country" (United Nations High Commission for Refugees, 1951/1967). For the purposes of this article, it is important to differentiate between accepted refugee and refugee claimant status* ${ }^{*}$ The term refugee claimant refers to someone whose claim is still under review. Refugee status describes someone whose claim from within Canada has been accepted by the Immigration and Refugee Board (IRB), or someone who has been preselected from another country to settle in Canada. The terms refugee claimant and migrant will both be used in this paper, and are not intended to totalize the identities of the people who arrived on the Sun Sea. The usage of these terms refers simply to their legal status in the eyes of the Canadian state and reflects terms used in public discourse.

\footnotetext{
* A discussion of permanent resident status will not be undertaken, as the focus of this paper is the families aboard the MV Sun Sea, who claimed asylum upon arrival.
} 
International Journal of Child, Youth and Family Studies (2012) 2 \& 3: 331-348

\section{Methodology: The Media As a Site of Analysis}

The media provides a rich site for analysis. Smolash (2009) argues that mass media texts are the most popular form of contemporary storytelling in our culture (p. 749). As seen above, the stories that nations tell about themselves distinguish them from other nations (Anderson, 1991, as cited in Mackey, 1999). Therefore, as Greenberg and Hier (2001) argue, the media serves as a means for society to tell and retell their most basic myths. Eventually, many of these myths become accepted truths about the supposed identity of the nation and its citizens. The centrality of stories and myths to nation building cannot be overlooked. What might these "stories" tell us about the ways in which children and families are being constructed in Canadian media, and within the Canadian imaginary? Whereas several Canadian scholars have analyzed the discursive construction of racialized migrants in media text, some of whom are cited in this discussion (Greenberg \& Hier, 2001; Jiwani, 2006; Smolash, 2007, 2009), the following analysis will focus on the comments sections, which appear beneath two online news articles. Public comments offered in response to online news stories offer a glimpse of how people are forever involved in the co-authorship of powerful cultural narratives.

Discourse analysis is "a method and a theory 'for studying language in its relation to power and ideology"” (Fairclough, 1995, as cited in Pacini-Ketchabaw et al., 2006, p. 100). The relevance of engaging in discourse analysis as human service professionals is to become aware of, and challenge, how the world, ourselves, and the people with whom we work are brought into existence through language in ways that are taken for granted. I elected to use comments posted on the Canadian Broadcasting Corporation (CBC) website, as the CBC enjoys country-wide distribution, and also because it presents itself as being reflective of Canadian national identity, and I was particularly interested in articulated perceptions of Canada's national imaginary as explored above.

It is important to mention that the comments cited below were submitted anonymously, which may have encouraged more aggressive and violent postings. Equally as important to mention is that the CBC monitors comments posted, and reserves the right to remove content that violates its specified "netiquette”. Under Article iv in the "Submissions" section of the CBC website's Terms of Use, it states that observing the rules of CBC netiquette means that users do not, "post or transmit any Submission that promotes racism, bigotry, hatred or physical harm of any kind against any group or individual, could be harmful to minors, harasses or advocates harassment of another person” (Canadian Broadcasting Corporation, 2011).

It is also instructive to reiterate that comments are posted in response to the media text itself and/or other comments, and in some instances, take up dominant state-driven discourses on migration. Thus the comments should not be understood as having emerged in a vacuum. Greenberg and Hier (2001) emphasize that “...the possibility of reader participation in collective problematization depends largely on the normative-emotional context and the ability of the text to amplify those aspects thought to have resonating 
International Journal of Child, Youth and Family Studies (2012) 2 \& 3: 331-348

qualities” (p. 566). Kamboureli (2000) argues that the media is incapable of telling complex, non-linear, contradictory stories and therefore tends to construct narratives of controversy (p. 89). While recognizing that the content of the articles may have influenced the narratives that emerged in the comments section, I am going to focus exclusively on the comments. One of the interesting advantages of using this particular site for analysis is the ability to note how many subsequent readers agreed or disagreed with the comment posted. I will track this in the discussion that follows by indicating how many readers had voted "for" or "against" selected comments at the time when the articles were accessed in December 2010.

\section{Discourse Analysis A}

The article entitled, “Tamil Migrant Ship Heading for B.C.” appeared on July 16, 2010 on the CBC website (CBC News, 2010, July 16). It was based on information that the Sri Lankan government had provided to the Colombo Sunday Observer about a ship heading towards Canada. The Sri Lankan government claimed that there were Tamil Tigers on board the vessel (as of March 2011, the Canadian government claimed to have found cause to deport only one person for apparent links to the Tamil Tigers). I deliberately chose a news story that preceded the boat's arrival in order to illustrate that even with extremely limited information about the people on the ship, respondents to the article reacted strongly, and at times aggressively. Also noteworthy is the fact that the term "illegal migrants" appeared in this story, one of the first articles covering the ship. While I will now attempt to analyze each discursive construction separately, I am cognizant that many of the comments weave various discourses together.

\section{Tamil migrants pose a threat to Canada and Canadians.}

Pratt (2005) writes, “refugees' real identities [are] presumed unknown, their credibility always suspect, and their links with criminality, security and fraud continually reconstituted” (p. 3). The people aboard the Sun Sea were constituted as threats in various ways. One person wrote, “...we can get ready for more terrorists being paid by us to live and train in Canada ...” (163 for, 14 against). This comment contains the "Us/Them" binary so often evoked in conversations about migration. The "Us" refers to the Canadian imaginary, against which otherness is juxtaposed (Jiwani, 2006). This comment also draws on resonant images of the deceitful and freeloading migrant described by Pratt (2005). Another individual posted, "This is the greatest country in the world, and we have to accept another boatload of terrorist trash" (25 for, 2 against). Combined with the dehumanization of everyone on the ship is a particular brand of Canadian nationalism. Given the ways in which specific racialized groups are constructed as terrorist threats in Canada (Smolash, 2009), this brand of nationalism is inflected with notions of racial superiority. Razack (2009) argues that in the context of a perceived perpetual threat, security and securitization both depend upon and produce race hierarchies (p. 15).

Secondly, the people aboard the Sun Sea were constituted as threats to Canada's white settler national imaginary. Despite being censored by the CBC, many of the postings were overtly racist. One person wrote, "I am glad I lived many years [sic] when Canada was full of Canadians not the drips I see every day now, they don't even speak 
International Journal of Child, Youth and Family Studies (2012) 2 \& 3: 331-348

our language in public ..." (23 for, 0 against). This respondent claims to "see" these drips every day, thereby constructing "Them" as discernible by appearance, or by the languages that "They" speak in public. This comment reveals the presumed colonial, white European origins of "real Canadians", and the reader's strong self-location as belonging to the collective "We" who speak "Our" language. The following comment seems to be calling for a limit on the number of migrants that Canada accepts from majority world countries: "This country is now officially a joke. Nice precedent you set last time immigration officials, now this will never stop. Maybe it will stop when 3/4 of Canada's population is of Third World origin?” (422 for, 37 against). This comment reveals the dual assumptions that the majority of Canada's population originates from "first world" countries, and that this majority needs to be protected. This comment also illustrates the expectation that the immigration system, and its technologies of deportation and detention, should be used to set precedents for other racialized would-be migrants.

Finally, the migrants aboard the Sun Sea were criminalized and positioned as threats to Canadian law and order. One person demanded, "Why should these illegals get in but hard working law abiding Europeans with lots to offer get turned away at immigration everyday while East Indians, Koreans, Chinese and other illegals get the red carpet. Enough is enough” (42 for, 3 against). What is interesting about this comment is the way in which this person defines illegal and legal. Legality and illegality are not depicted as legal statuses determined through due process of law, but are ontologized carried within and on the body. Several comments linked what they perceived as legal forms of immigration with Europeans, while racialized people were associated with illegality, queue jumping, and fraud. Another person claimed, “...just like all the Haitians we took in after the earthquake, I wonder how many of them are criminals that will only contribute to the raise [sic] of violence and crime in the neighbourhoods of Montreal??” (43 for, 1 against). The idea that migrants carry criminality and illegality on their bodies was a pervasive sentiment in the postings, and is part of a broader discourse that criminalizes racialized bodies and positions them as enemy others (Smolash, 2009). As Hall (1978) astutely pointed out, "Labeling an activity, person, or group of persons as 'criminal' is often part of a broader strategy of repression and control, only some aspects of which belong to the exercise of crime-prevention and control in any normal sense" (as cited in Mirchandani \& Chan, 2002, p. 15).

Given the pervasive construction of Tamil migrants as threats, it is perhaps not surprising that some people called for military intervention in the name of protecting Canada's borders. One person wrote, "Use whatever force is necessary to defend Canada's border from illegal entry attempts” (121 for, 7 against). Over 10 postings disconcertingly called for the Canadian military to attack the ship. One responder wrote, "Our navy should be dispatched to the boarder line. If the ship crosses it shoot a few rounds across the bow and force it to turn around" (150 for, 9 against). Another reasoned, "A boatload of illegal Tamils will cost the taxpayers $\$ 10 \mathrm{M}+$ a torpedo goes for how much?” (35 for, 7 against). Jiwani (2009) urges us to recall that racial hierarchies are not created strictly through the practices of government security apparatus or local police forces, but are practiced by the wider public. The above comments illustrate how security discourses have been internalized, taken up, and adopted by individuals to form powerful 
International Journal of Child, Youth and Family Studies (2012) 2 \& 3: 331-348

narratives that end up constituting widely accepted "truths". Security discourse plays a central role in shaping Canadians' perception of migrants as threatening invaders, and in so doing, prompts Canadians to desire and defend policies that make it more difficult for migrants to enter and stay in the country.

Security discourse also positions Canada as "the victimized Subject of violent 'Otherness': the Subject under threat of invasion, the Subject whose sovereignty is being undermined and the Subject who is being blackmailed and abused by illegal entrants" (Parr, 2005, p. 284). Citing Brodie, Razack (2009) emphasizes that while security discourses change over time, the citizen-state security relationship is bound to a racially inflected sense of nationalism (p. 816).

\section{Tamil migrants are fraudulent refugees.}

Tamil individuals and families aboard the Sun Sea were also constructed as fraudulent queue jumpers. Demonstrating an almost complete ignorance of the immigration and refugee claims process, one commentator wrote, "As Canadians we grow up believing in fairness and waiting our turn. Bogus refugees violate Canadian social norms by not waiting their turn and line jumping ahead of highly skilled workers who can and will be productive members of Canadian society”. This comment blends a discourse of Canadian benevolence and civility with neo-liberal notions of what it means to be a productive member of society. Believing in fairness, and waiting one's turn are ontologized as Canadian. The Other, the bogus refugee, is denied belonging to the Canadian "we", and by extension, denied access to the articulated values. Sarah Ahmed (2010) writes, “'illegal immigrants' and 'bogus asylum seekers' are those who are 'not us', and in not being us, endanger what is ours" (p. 1) as legitimate subjects of the nation. Within this discouse, productivity is linked concretely to skilled workers status, another way for people to enter Canada. Furthermore, by constructing refugee claimants as manipulative frauds, the migrants' justified claims to a better life are preemptively delegitimized. By positioning them as frauds - people who drag their children across the sea in a cramped boat for ostensibly no reason - they are othered in a way that renders them unknowable to "Us", we Canadians. When one person on the site suggests that the Tamil families should have gone through the "proper" channels, another responds, "Somehow that type of logic doesn't work with certain cultures...”. Here, respecting the law is reduced to a cultural trait. As Razack (1998, as cited in Jiwani, 2006) points out, race is often culturalized. Following this logic, respect for the law and the ultimate ability to integrate into the Canadian context then becomes dependent on one's race.

The positioning of Tamil migrants as fraudulent refugees discursively constructs Canada and its citizens as victimized Subjects, which has several important consequences. First, it renders the past and present of Canadian nationhood, rooted in colonial aggression and racialized exclusion, inaccessible through dominant discourse. Writing about the Australian context, which has striking parallels to Canada, Anderson and Taylor (2005) assert that settler-society anxiety regarding invasive and threatening refugees originates in the unreconciled colonial origins of the nation. They write, "indigenous dispossession is both the foundational act that secured white sovereignty and the residual effect that continues to disturb it" (p. 465). Second, the framing of the state 
International Journal of Child, Youth and Family Studies (2012) 2 \& 3: 331-348

and its citizens as victims, "demands symbolically an agent who can respond to the crisis decisively” (Greenberg \& Hier, 2001, p. 575). Thus, adopting a victimized subjecthood contributes to the strengthening of the nation-state.

\section{Tamil migrants and neo-liberalism.}

Neo-liberal discourse constructs the migrant (particularly the refugee claimant) as a drain on the system. This discourse was visible in many of the comments posted in response to the CBC article. One person wrote, "I hope your taxes are paid up 'coz they'll be needing a lot of welfare and medicare” (145 for, 7 against). As Roberts and Mahtani (2010) assert, neo-liberal policies disproportionately impact racialized, economically vulnerable people, and then effectively blame those same people for their reliance on the system for survival. One person asserted, "Most of these immigrants are functionally illiterate in their own language and we expect them to be productive members of Canadian society. For every one we take in there are 10 more who will be sponsored under the family class."

The neo-liberal emphasis on individual agency and the simultaneous depoliticization of social issues greatly impacts public understandings of migration. At the macro-level, systemic production of migrations is rendered irrelevant within available public discourses (Sharma, 2004). The conditions that propel migrants from their countries of origin are often assumed to be unrelated to Canadian foreign and economic policy, or global systems of power that favour the West. These popular misconceptions thus "support a discourse in which the North's humanity is defined through its 'benevolent' acceptance of immigrants and refugees” (Folson \& Park, 2004, p. 13). Sharma (2004) argues that the host as benevolent and passive agent echoes historic claims to the white man's burden, and ties the notion of progressiveness to whiteness.

\section{Tamil migrants and benevolent multiculturalism.}

Tolerance discourse, characteristic of liberal multiculturalism, also appeared in many of the comments posted. As explored in the above section concerning tolerance language in self-proclaimed “multicultural” societies, Anderson and Taylor's (2005) assertion that tolerance is adopted as a distinguishing characteristic of multicultural societies featured prominently in the responses to this article. Kamboureli's (2000) concept of multicultural fatigue also surfaces in the responses. The following comment incorporates both of these elements: "I was raised with Canadian values of politeness, tolerance, acceptance. Even I can't stand these types of stories anymore. I've totally lost my patience and sympathy” (154 for, 10 against).

Brown (2006) asserts that the notion of tolerance, as it is employed in modern liberal-democratic societies, constructs the objects of tolerance as undesirable or deviant by virtue of having to be tolerated. Those who tolerate choose to do so, and this power of choice paves the way to superiority through benevolence (Brown, 2006, p. 14). Tolerance language also makes use of words like "sensitivity" and "respect” to negotiate political solutions to issues of diversity, which Brown (2006) argues is a dangerous practice of depoliticization that reduces issues of social justice to sensitivity training. 
International Journal of Child, Youth and Family Studies (2012) 2 \& 3: 331-348

\section{Discourse Analysis B}

I also chose to analyze the comments posted in response to the article, "Tamil migrant children start school in B.C.”, which appeared on the CBC online website on September 27, 2010 (CBC News, 2010, September 27). I was curious to explore whether migrant children were being constituted differently than adults through dominant discourse. This article reiterated Canada's official position concerning the detention of child migrants, which states that children themselves are never officially detained, but rather accompany their parents into detention facilities. At the time that this article was written, 54 children were being held at the Burnaby Detention Centre under the care of approximately 25 mothers, and the article announced that 41 children had begun classes and early childhood development programs (CBC News, 2010, September 27). After a traumatic three-month journey at sea, the Education District's Director of Instruction emphasized that the children felt safe in the detention facility, as evidenced by their joking and interacting with one another (CBC News, 2010, September 27).

\section{Guilty parents, innocent children, and Canadian benevolence.}

What is most striking in looking at the comments to this news story is the discrepancy between how children and parents were each constructed through dominant narratives. The same discourses that racialize and criminalize children's parents were cited in tandem with dominant Western discourses on childhood to mobilize narratives of Canadian benevolence. One comment read, "We cant criticize the govt for providing education to innocent children”. While discourses of racialization and neo-liberalism also constructed children in similar ways as their parents, children were repeatedly constructed as innocent.

In this context, discourses on the innocence of childhood served to further position migrant parents as guilty perpetrators. Canadian benevolence in this context then is interpreted, in part, as the responsibility to help and "protect" innocent children from their parents. One comment argued, "The children still are not responsible, nor should they be punished for the actions of their parents” (9 for, 42 against). Another pleaded, "Can we not agree that at least the young children are innocents here? Even if these were the children of terrorists - which nobody has proven they are - would that not be all the more reason to give these children the benefit of an education while their parents are detained so that they can break the cycle?" Another individual posted, "It is these kinds of moral standards that assures Canada does not disintegrate into the hell holes that so many countries have become for their people. We give up our humanity we give up what has kept Canada strong and alive” (13 for, 66 against). Canada, the nation, and Canadians are once again positioned as benevolent. However, articulated in the above comments about children and parents is an imperative for the state to step in and take charge of these children, to help these children break the cycle, and save them from the hellholes that their countries have become. The implication here is that these parents are guilty of something, and that this guilt can be passed down to their children unless the Canadian state intervenes. 
International Journal of Child, Youth and Family Studies (2012) 2 \& 3: 331-348

Several people went further and claimed that parents were intentionally using their children as a means to stay in Canada. Comments such as these were not uncommon, “...in this case children are the tools to get naive Canadians stuck and caught by sympathy” (19 form 3 against) and “...Canada should not allow the Tamils to use their children as a means of justification to live in Canada” (25 for, 3 against). Again, this discourse dehumanizes parents by assuming that they are using their children as props for personal gain, instead of having brought their children to Canada because they are tied to one another through the bonds of loving family relationships.

\section{Migrant children and neo-liberalism.}

Discourses of neo-liberalism also seemed to apply differently to children. While parents were positioned as drains on the system, children were more likely to be considered wise investments in the future. One person wrote, "Although it is costing me money, I am glad that I, as a Canadian, am helping these children” (511 for, 377 against). What might be at work behind the construction of children as innocents, and wise investments, while their parents are constructed as dangerous, criminal, and fraudulent? Ahmed (2004) examines how to be moved by the suffering of some others, in this case the innocent child, is

also to be elevated into a place that remains untouched by other others (whose suffering cannot be converted into my sympathy or admiration). So it is not a coincidence that it is the child's suffering that touches the nation. The child represents the face of innocence; through the child the threat of difference is transformed into the promise or hope of likeness. (p. 192)

What Ahmed means in referring to the promise of likeness is mixed-raced hybridity, which the nation fetishizes and loves as a reflection of its imagined self - a tolerant and benevolent nation. Ahmed (2004) explains, "In other words, the nation remains an agent of reproduction: she (the child) is the offspring of multicultural love for difference” (p. 137).

\section{Racialized migrants as a threat to the Canadian imaginary.}

Finally, several comments drew from discourses of racialization, which simultaneously positioned racialized migrant children as "Others" and asserted Canadian identity as one rooted in hegemonic whiteness. The following comment illustrates these discourses in disturbing clarity:

I mean think about the country we all love, the Canadians who built this great nation, and the slow decay of the invisible majority over the preferences of the visible minorities. Think about what we as a Christian nation are losing. What we as a majority are giving up for the benefit of Affirmative Action and multiculturalism. The essence of Canada will dry up and die if something isn't done to reinforce Canadian values... (115 for, 9 against)

This comment constitutes racialized migrants and all racialized people as a direct threat to Canadian values. Smolash (2009) articulates the effects of racialization when she 
International Journal of Child, Youth and Family Studies (2012) 2 \& 3: 331-348

writes:

Racialization shapes how human bodies are perceived, and, to echo Foucault, inscribes meaning on the human body, marks the body with a particular value. The identities of those who enter into a racialized discourse are reconstituted by these inscriptions; for instance, immigrants who leave home communities, in which their identity may be the norm, and become racialized within Canada, are transformed by this migration in space and in raced identity. (p. 747)

Processes of racialization are complex, and as Smolash points out, inscribe people differently in different contexts.

\section{Conclusion}

The narratives explored in the comments above, framed within discourses of racialization, multiculturalism, national security, and neo-liberalism, have significant implications for child and youth care practitioners. The online comments illustrate how dominant discourses can intersect and converge to dehumanize children and families. In child and youth care, how might we resist complicity in the replication of oppressive practices with children and families? While I do not have a simple, prescriptive answer, I believe that pedagogy, particularly education in the human services, needs to move away from discourses of multiculturalism and tolerance towards a critical, activist oriented analysis of power and oppression in "multicultural” Canada based on social justice. I also propose that theory can serve as an extremely important starting point. As a tool, theory can be used to unmask the powerful narratives that normalize the everyday violence perpetrated against many of people with whom we work. "In particular, theory can provide a positive ideology in its ability to seek out the problems that a text poses and test the new innovative possibilities such questions put forward” (Parr, 2005, p. 294).

Some questions have sprung from the problems that these media comments highlighted for me: Who has access to constructions of the good parent, the right type of childhood, and the loving family? How does constructing parents in the ways explored above affect children and families? And finally, what do children, youth, and families know about these processes, and how might they be navigating, exploring, and challenging Otherness and Othering practices? These are complex questions that require fluid, context-based, and flexible responses. 
International Journal of Child, Youth and Family Studies (2012) 2 \& 3: 331-348

\section{References}

Abu-Laban, Y. (1998). Welcome/STAY OUT: The contradiction of Canadian integration and immigration policies at the millennium. Canadian Ethnic Studies, 30(3), 190211.

Abu-Laban, Y., \& Gabriel, C. (2008). Selling out diversity in an age of globalization. In M.A. Wallis \& S. M. Kwok (Eds.), The deepening racialization and feminization of poverty in Canada (pp. 47-57). Toronto: Canadian Scholars' Press.

Access Alliance Multicultural Community Health Centre. (2007). Racialization and health inequalities: Focus on children. Retrieved from http://accessalliance.ca/sites/accessalliance/files/documents/Racializationand HealthInequalities.pdf

Ahmed, S. (2004). The cultural politics of emotion. New York: Routledge.

Anderson, K., \& Taylor, A. (2005). Exclusionary politics and the question of national belonging: Australian ethnicities in “multiscalar” focus'. Ethnicities, 5(4), 460485.

Bannerji, H. (2000). The dark side of the nation: Essays on multiculturalism, nationalism and gender. Toronto: Canadian Scholars’ Press.

Biles, J., Burstein, M., \& Frideres, J. (Eds.). (2008). Immigration and integration in Canada in the twenty-first century. Kingston, ON: McGill-Queens University Press.

Brown, W. (2006). Regulating aversion: Tolerance in the age of identity and empire. Princeton, NJ: Princeton University Press.

Canadian Broadcasting Corporation (CBC). (2011). CBC policies: Terms of use. http://www.cbc.ca/aboutcbc/discover/termsofuse.html

Canadian Council for Refugees. (2011). Myths and facts 2011. Retrieved from: http://ccrweb.ca/en/myths-and-facts-2011

CBC News. (2010, July 16). Tamil migrant ship heading for B.C. Canadian Press. Retrieved from http://www.cbc.ca/canada/britishcolumbia/story/2010/07/16/bc-migrant-ship.html

CBC News. (2010, September 27). Tamil migrant children start school in B.C. CBC News. Retrieved from http://www.cbc.ca/canada/britishcolumbia/story/2010/09/27/bc-tamil-migrant-children-school.html 
International Journal of Child, Youth and Family Studies (2012) 2 \& 3: 331-348

Citizenship and Immigration Canada. (2010). Facts and figures 2009 - Immigration overview: Permanent and temporary residents. Retrieved from http://www.cic.gc.ca/english/resources/statistics/facts2009/temporary/03.asp

De Genova, N., \& Peutz, N. (2010). The deportation regime: Sovereignty, space and the freedom of movement. London: Duke University Press.

Department of Justice Canada. (2001). Immigrant and refugee protection act (IRPA). Retrieved from http://laws-lois.justice.gc.ca/PDF/I-2.5.pdf

Folson, R. B., \& Park, H. (2004). Introduction. In R. B. Folson (Ed.), Calculated kindness (pp. 11-20). Halifax, NS: Fernwood Publishing.

Greenberg, J., \& Hier, S. (2001). Crisis, mobilization and collective problematization: "Illegal" Chinese migrants and the Canadian news media. Journalism Studies 2(4), 563-583.

Jiwani, Y. (2006). Reframing violence. In Discourses of denial: Mediations of race, gender, and violence (pp. 3-29). Vancouver, BC: UBC Press.

Jiwani, Y. (2009, November 4). Every breath you take: Surveillance, security and the end of privacy. Concordia University President's Conference Series. Retrieved from: http://www.youtube.com/watch?v=Wf3jzSeYkc\&playnext=1\&list=PL555C25596DDC2FB6\&index=8

Kamboureli, S. (2000). Sedative politics. In Scandalous bodies: Diasporic literature in English Canada (pp. 81-130). Don Mills, ON: Oxford University Press.

Kenney, J. (2009, March 18). Good citizenship: The duty to integrate. Speaking notes for the Honourable Jason Kenney, PC, MP, Minister of Citizenship, Immigration and Multiculturalism. Retrieved from http://www.cic.gc.ca/english/department/media/speeches/2009/2009-03-18.asp

Mackey, E. (1999). The house of difference: Cultural politics and national identity in Canada. London: Routledge.

Mirchandani, K., \& Chan, W. (2002). From race and crime to racialization and criminalization. In W. Chan \& K. Mirchandani (Eds.), Crimes of colour: Racialization and the criminal justice system in Canada (pp. 9-22). Orchard Park, NY: Broadview Press.

Pacini-Ketchabaw, V., White, J., \& Armstrong de Almeida, A-E. (2006). Racialization in early childhood: A critical analysis of discourses in policies. International Journal of Educational Policy, Research, and Practice: Reconceptualizing Childhood Studies, 7(1), 95-113. 
International Journal of Child, Youth and Family Studies (2012) 2 \& 3: 331-348

Parr. A. (2005). The deterritorializing language of child detainees: Self-harm or embodied graffiti? Childhood, 12(3), 281-299.

Pratt, A. (2005). Overview and orientations. In Securing borders: Detention and deportation in Canada (pp. 1-22). Vancouver, BC: UBC Press.

Razack, S. H. (2009). Afterword race, desire and contemporary security discourses. University of Toronto Quarterly, 78(2), 815-820.

Robinson, T. L. (2000). Multiple identities defined. In T. L. Robinson \& M. F. HowardHamilton (Eds.), The convergence of race, ethnicity and gender: Multiple identities in counseling (pp. 1-21). Upper Saddle River, NJ: Prentice Hall.

Roberts, D. J., \& Mahtani, M. (2010). Neo-liberalizing race, racing neo-liberalism: Placing “race” in neo-liberal discourses. Antipode, 42(2), 248-257.

Sharma, A. (2004). Productions and patterns of the migrant body: Early South-Asian migration to Canada. In R. B. Folson (Ed.), Calculated kindness (pp. 33-43). Halifax, NS: Fernwood Publishing.

Skott-Myhre, H. (2008). Youth and subculture as creative force: Creating new spaces for radical youth work. Toronto: University of Toronto Press.

Smolash, W. N. (2007). News and the World Wars: A geneology of Canadian discourse about the "enemy within". Retrieved from http://nofcit.com/papers/Essay_N.\%20Smolash.pdf

Smolash, W. N. (2009). Mark of cain(ada): Racialized security discourse in Canada's national newspapers. University of Toronto Quarterly, 78(2), 745-763.

United Nations High Commission for Refugees. (1951/1967). Convention and protocol relating to the status of refugees. Retrieved from http://www.unhcr.org/3b66c2aa10.html

United Nations High Commission for Refugees. (2010, June). 2009 global trends: Refugees, asylum-seekers, returnees, internally displaced and stateless persons. Retrieved from: http://www.unhcr.org/4c11f0be9.html 